\title{
Exploration of Design Development Borobudur Chair with The Aèng Method (strange)
}

\author{
Rahmanu Widayat ${ }^{1}$, Anung B Studyanto ${ }^{2}$ \\ ${ }^{1}$ Department of Interior Design, Faculty of Arts and Design, Universitas Sebelas Maret, Surakarta, Indonesia \\ ${ }^{2}$ Department of Interior Design, Faculty of Arts and Design, Universitas Sebelas Maret, Surakarta, Indonesia \\ rahmanuwidayat@staff.uns.ac.id (Rahmanu Widayat), anungbs@staff.uns.ac.id (Anung B Studyanto)
}

\begin{abstract}
The Borobudur chair originated from the reconstruction of seat image (two-dimensional) in the Borobudur Temple relief in Central Java Province Indonesia. This reconstruction process produces a replica of Borobudur Chair and has redesigned the chair with wangun or indah concept (Javanese beauty concept). In the Javanese context culture, the anti-thesis of wangun concept is aèng or strange, both come together in the creation of Javanese beauty concept. There are some problems when the Borobudur Seat is explored and developed by various possibilities of design with the aèng method. The aèng method in the Western world is similar to the method of distorted changes (refraction) and destruction and others. As a result, there is a chair that enters into group of artworks. The Borobudur chair as an artwork cannot be judged from the calculation of material prices, a cost of artisans, final settlement, and profit gained. Artwork is appreciated for its beauty that is highly valued by the public, critics, and art collectors. Certainly, the Borobudur Chair design development with the aèng method is still processed. The stages which have to be taken is an exhibition to measure how this work accepted by the society.
\end{abstract}

Keywords exploration, Borobudur Chair, the Aèng method

\section{Introduction}

This study is important because it is the third stage that researchers have done from 1) reconstruction of Borobudur Seat with the result of replica, 2) development of replica design of Borobudur Chair with wangun concept, 3) this time, the researcher explores the development of Borobudur Chair design with aèng method, which is anti-thesis of the wangun method. Exploration as the basis for design development with the aèng method becomes important, as it produces many different possible design features. This kind of creativity is required in the world of fine art and design to avoid stagnation in artwork. in the West, many have conducted research in the field of study of the creation or exploration of the development of this chair design.

Some start from art until they become chairs and vice versa, some also from chairs to different seats. Seeing the work of previous creation, as Gerrit Rietveld did in 1917 which made the seat but has not yet finished. In 1920, appeared a painting entitled Composition with Red, Black, Blue, Yellow, and Gray by Pieter Cornelis Mondrian. In 1923 this painting inspired Gerrit Rietveld to color his chair into a chair that has the characteristic group of de stijl titled Red and Blue Chair. ${ }^{1}$ Kandissi Sofa 1980 by Allesandro Mendini (Fiell, 1991: 133), this is an exploration of paintings by Wassily Kandinsky circa 1923 into a sofa. ${ }^{2}$ The exploration of the classic chair design development of the Quen Anne Chair ${ }^{3}$ (1740) style by Robert Venturi became a Postmodern style chair named "Quen Anne Chair Robert Venturi" in the 1980 s $^{4}$.

Some design explorations as a reaction to modern furniture design concepts include seats performed by designers of Memphis Style or Memphis Design groups of the 1980s. A style or a design that not only pursues functionality

${ }^{1}$ Look at

http://www.theartstory.org/movement-de-stijl-artworks.htm.

${ }^{2}$ Look at http://www.wassilykandinsky.net/work-50.php

${ }^{3}$ Look at

https://en.wikipedia.org/wiki/Queen_Anne_style_furniture

${ }^{4}$ Look at https://id.pinterest.com/pin/566327721866921565 
but emphasizes exploration into chairs and other furniture for visual enjoyment ${ }^{5}$.

Next comes the question, what is the difference of the previous creation compared with the exploration of the Borobudur Chair with the method aèng or strange? The difference lies in the starting point of creation that is the Borobudur Chair reconstructed from the cultural heritage of the 8th century. The different sources of this idea will give birth to a design that is colored by local culture and not just global culture, dominated by Western culture. This is done to fill the void in the development of the seat design of local cultural products that have a visual age of about a thousand years to be present again in modern times today. Based on this process, Borobudur Chair will be born different model and does not cover the possibility included in the fine art group besides applied art. In fact, at this time, grouping like this is more flexible in its application. The purpose of exploring the development of Borobudur Chair designs to produce good seats in terms of appearance, material, color, construction, and others.

Furthermore, this work and development can be socialized through the exhibition in order to get criticism, suggestions, and even expected to get appreciation or recognition as a creation process with the aèng method, which has the characteristic of the mix of ancient design with the present. The findings of the research process of this creation, that is when the method aèng applied to explore the source of the idea of Borobudur Chair, has led to different results different, which is sometimes characterized as a design and art. This is an important contribution to the application of the aèng method to explore the development of Borobudur Chair design in the field of fine arts and design, since the concept and methods have not explicitly been applied in the academic world. This article is composed of title, abstract, keyword, introduction, literature and theory, data and methods, result and discussion, ending with conclusion.

\section{Literature and Theory}

The literature associated with the exploration of change from one form is called deformation, which has been

\footnotetext{
${ }^{5}$ Look at

https://creativemarket.com/blog/trend-alert-1980s-memphis -design.
}

studied by Western experts. Deformation is a deliberate change of form for the sake of art, which often seems so strong that it sometimes no longer represents a form like the original figure or the real one. Changes from this form bring up new figures / characters other than before. As for how to change the form, among them is by simplification (simplification), distortion (refraction), destruction, stylization /styling, or a combination of all the arrangement of the form (mix) (Susanto, 2012: 105). The theory or concept used for the exploration of the development of Borobudur Chair design is the concept of aèng which the explanation as follows.

Aèng berkonotasi anèh atau ora njawani (bukan Jawa), hal ini terjadi bila tidak berpedoman pada landasan alam pikiran orang Jawa. Aèng berdiri di antara wangun dan ora wangun, karena aèng bisa masuk kelompok wangun, dan dapat masuk kelompok ora wangun, atau tetap aèng saja atau anèh, ora njawani. Aèng bisa menjadi wangun jika digandrungi atau menjadi tren. Aèng juga bisa menjadi wangun bila sudah menjadi kebiasaan - pakulinan atau dianggap lumrah. Aèng-pun bisa menjadi wangun bila mendapat legitimasi raja-zaman kerajaan. Aèng yang wangun karena menjadi kebiasaan dan legitimasi raja adalah di luar pedoman alam pikiran orang Jawa (Widayat, $2016: 216-217$ ).

[Aèng connotes anèh (strange) or ora njawani (not Javanese), this happens when not guided by the Javanese mind base. Aèng stands between wangun (beautiful) and ora wangun (not beautiful), because aèng can enter the wangun group, and can enter the group or wangun wawa, or stay aèng alone or anèh, ora njawani. Aèng can be wangun if loved or become a trend. Aèng can also be wangun when it becomes a habit/routine or considered as commonplace. Aèng can be wangun if it gets legitimacy by the king/by the kingdom. Aèng which becomes wangun because of the custom and legitimacy of the king is outside the guidance of the minds of the Javanese (Widayat, 2016: 216-217).]

Aèng as a concept has produced something that attracts attention in the city of Solo (Surakarta), Central Java Province, Indonesia. This concept is often used by "Repub- 
lic Aeng-Aeng" with his President, Major Haristanto and his work in using this concept has been significant ${ }^{6}$.

Associated with aèng or strange, James T. Siegel in his book, Solo in the New Order: Language and Hierarchy in an Indonesian City, wrote a phenomenon in the city of Solo during the New Order government (circa 1980s) called "the weird ". In essence, the Solo people are faced with a transformation into an unrecognizable and difficult world placed back in a familiar world, an interesting example of "the weird" is the show of Sri Mulat with Dracula (Siegel, 114: 1986). Strange or aèng in this research deliberately used as a method to produce a different form, the results may be weird and funny. Like the show Sri Mulat with the presence of Dracula (ghost of the West) to make the audience not afraid but laugh out loud. The literature of transfiguration in the West that is close to the concept of aèng in Java according to the author is the distortion (refraction) and destruction.

Distortion of shape changes; deviation; circumstances are bent. In photography is called pemiuhan. Needed in art work, because it is one way to try to explore other possibilities on a form / figure.

Distraction is a confusing state to break people's attention (Susanto, 2012: 107).

\section{Page Style}

The data as a source of ideas or starting point of exploration is taken from the result of our research entitled Reconstruction of "Borobudur Chair" (to support creative industry) in 2015, which is one of the findings of replica of O-75 Borobudur Chair. The method used is a visual interpretation with the approach of distortion or refraction, visual destruction and others to produce a new image.

${ }^{6}$ Look at http://dok.joglosemar.co/baca/2015/05/31/ma yor-haristanto-presiden-republik-aeng-aeng- membaca-berita-media-bikin-kreatif.html).

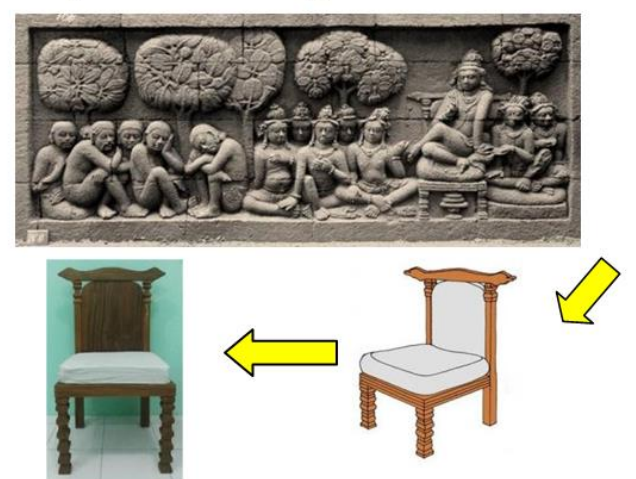

Figure 1. One of Borobudur Chair replicas as starting point of exploration of design development (research entitled Reconstruction of "Borobudur Chair" (to support creative industry) in 2015)

\section{Result and Discussion}

The exploration stage of Borobudur Chair design development with aèng concept can be explained as follows.

1. As an idea source is a replica of Borobudur Chair.

2. The replica of the Borobudur Chair was developed by designing methods such as distortion, destruction, and other means by the creators based on the comprehended concept of Aèng method.

3. Sketch stages of perspective from the form of Chair Borobudur Aèng, which is a form of visual interpretation by aèng method of the replica of Borobudur Chair.

4. Based on several alternatives, one is chosen and being made for its drawing

5. Sketches that have been drawn will then be made in the form of mock-up.

6. Mock-ups are displayed in an exhibition to get responses from art lovers and design communities, critics, collectors, and others.

Changes from the replica of the Borobudur Chair become aèng, as art furniture is a form of artistic expression of its creator (Pile, 1995: 389). Stages of change visually are as follows.

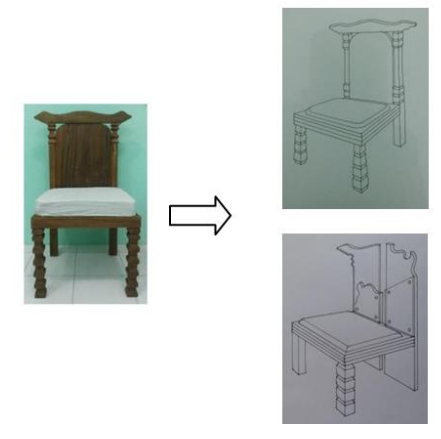

Replica of Borobudur Chair as the starting point of exploration

Figure 2. Exploration of Development of Borobudur Chair Design with Aèng Method 


\section{Conclusion}

Based on the exploration experiments of the design of the Borobudur Chair with the concept of aèng prove that the original functional design work can be transformed into a work of art because of the freedom of interpretation of deformation with the concept of aèng, such as distortion or refraction and destruction. The freedom that is given is not only a change of form, but material change, final settlement, and coloring produce a dynamic work. Recognition as a work of art is not easy, but it takes time and a long process through various art exhibitions.

\section{ACKNOWLEDGEMENT(S)}

Acknowledgments to the Rector of the University of Sebelas Maret who has funded this research through PNBP funds

\section{REFERENCES}

[1] Fiell, Charlotte and Fiell, Peter. 1991. Modern Furniture Classics Since 1945. London: Thames and Hudson Ltd.

[2] Pile, John F., 1995. Interior Design. New York: Harry N. Abrams, Inc., Publishers

[3] Siegel, James T. 1986. Solo in the New Order: Language and Hierarchy in an Indonesian City. Princeton, New Jersey: Princeton University Press. (E-book Version: http://press.princeton.edu/titles/2469.ht ml)

[4] Susanto, Mikke. 2012. Diksi Rupa Kumpulan Istilah dan Gerakan Seni Rupa. Yogyakarta: DictiArt Lab \& Djagad Art House.

[5] Widayat, Rahmanu, dkk. 2015. Rekonstruksi "Kursi Borobudur" (Untuk Menunjang Industri Kreatif), Penelitian Unggulan Perguruan Tinggi (PUPT) Tahap I, Fakultas Seni Rupa dan Desain, Universitas Sebelas Maret Surakarta.

[6] Widayat, Rahmanu, 2016, Estetika Barang Kagunan Interior Dalem Ageng di Rumah Kapangeranan Keraton Surakarta, Disertasi Program Pascasarjana Institut Seni Indonesia (ISI) Surakarta.

[7] http://dok.joglosemar.co/baca/2015/05/31/ma yor-haristanto-presiden-republik-aeng-aeng-membaca-berita -media-bikin-kreatif.html

[8] http://www.theartstory.org/movement-de-stijl-artworks.htm

[9] http://www.wassilykandinsky.net/work-50.php

[10] https://creativemarket.com/blog/trend-alert-1980s-memphisdesign

[11] https://en.wikipedia.org/wiki/Queen_Anne_style_furniture

[12] https://id.pinterest.com/pin/566327721866921 